\title{
Raising the Standards: ICT and the Teacher of the Future
}

\author{
Ian Webb and Toni Downes \\ Technology Education Federation of Australia, P.O. Box 1255, ACT 2616, Australia, \\ ian.webb@dicksonc.act.edu.au,t.downes@uws.edu.au
}

\section{INTRODUCTION}

The last five years in Australia have seen the intensification of activity around teacher standards. There have been a number of initiatives at the national level, including the development of standards for accomplished teachers of Mathematics, Science and English. A number of state education systems have also undertaken work in this area - for example in Western Australia (EDWA, 2001) and Queensland (Education Queensland, 1998, 2001). More recently some attention has been paid to the matter of teacher standards and the integration of ICTs into teaching and learning in classrooms.

The national statement Learning in an Online World: The School Education Action Plan for the Information Economy (Commonwealth of Australia, 1999) outlines a range of objectives and associated strategies in the application of information and communication technology (ICT) in teaching and learning. One such strategy in the area of 'People' is the development of teacher ICT standards for the use of ICT in the curriculum and incorporation of those standards into human resource management within education authorities and schools. More recently, the Making Better Connections report (DETYA, 2001) recommended that governments, systems and teacher education institutions and professional associations work collaboratively to develop standards for beginning and advanced teachers, standards for school-based and system-level capacity and for teacher education programmes and institutions, to support the student outcomes, and the linking of professional development strategies to these benchmarks and standards.

The original version of this chapter was revised: The copyright line was incorrect. This has been corrected. The Erratum to this chapter is available at DOI: 10.1007/978-0-387-35701-0_35 
In response to these recommendations and other activities at national and state levels, the Commonwealth Department of Education, Science and Training (DEST) funded a project to develop a proposal for a national framework for ICT standards for teachers - both pre-service and practicing teachers. The project was conducted from July 2001 to January 2002.

The overall focus of the project was the development of a framework proposal, which could be used by teacher education institutions, teacher employers and professional associations to develop ICT standards relevant to their purposes and contexts.

The project was conducted in three phases. The first phase comprised:

- a review of the literature;

- an exercise in mapping current policy and practice in regard to teacher professional standards in Australia (national, state and territories) and selected overseas countries (United States, United Kingdom, Canada, Denmark and New Zealand);

- an analysis of the significant issues relevant to ICT competence in teaching and learning. The findings of this phase were reported in a preliminary report: Literature Review and Mapping document.

The second phase of the project was a two-day national forum of key stakeholders held in Canberra in October, 2001. The purpose of the forum was to seek input on the issues raised in Phase One, and on the direction of the project. A full report on the forum is included as an appendix to the final project report.

The third phase involved further analysis of findings, issues and outcomes from the forum, leading to the generation of a draft ICT Standards Framework proposal.

This final report, Raising the Standards, has been published on the DEST website at http://www.dest.gov.au/schools/publications/2002/ raisingstandards.htm. The report comprises the following sections:

- a proposal for an ICT Standards Framework including analysis of the important issues and recommendations derived from the first and second phases;

- a proposed structure for an ICT Standards Framework;

- a proposal for ways in which this work can be supported and shared at a national level;

- two appendices comprising a report on the national two-day forum and a forum participant list;

- the Literature Review and Mapping as a third appendix.

A review of the literature and experiences overseas and in Australia revealed that the development of teacher professional standards is not without controversy. There are a number of tensions and contentious issues surrounding both non-ICT specific and ICT specific standards. A key matter 
of contention was whether there should, indeed, be a separate set of ICT specific standards, or whether a better option is to develop generic standards with rich descriptors that involve the use of a wide range of ICTs.

The final report addresses the following issues, and makes recommendations about each:

- language and the nature of competence;

- importance of context;

- supporting capabilities;

- issues of equity;

- relationships to other standards developments;

- a performance management or a professional development model;

- separate or embedded ICT standards;

- generic or subject specific ICT standards;

- standards for levels of teachers or a continuum of development;

- a minimum set of ICT standards for all teachers;

- dimensions of ICT use and stages of development;

- the relationship between non-ICT specific and ICT specific standards;

- who should develop, implement and assess the standards;

- teacher ICT competence, curriculum and student learning outcomes;

- framework evaluation and review processes.

The following formed the key recommendations of the project.

\section{TECHNICAL COMPETENCE OR A COMPREHENSIVE VIEW OF ICT COMPETENCE}

The notion of competence with regard to the use of ICT in education was regarded as broader than the technical skills needed to use ICT. The report stated that to take a technical view of competence would be to deny the plethora of skills needed by teachers to create meaningful and productive learning contexts for students. Therefore, whilst it may be easy to take a technical view of ICT competence, the report argued that it is not sufficient to equip teachers to understand and make effective use of ICT in the classroom. The type of ICT competence needed by teachers is a collection of knowledge, skills, understandings and attitudes that are inextricably bound up with context and pedagogy. The report recommended that "for the purposes of this framework, and standards that may be developed from it, a comprehensive view of competence is to be taken. That such a comprehensive view includes technical and higher order cognitive knowledge, skills, understandings and attitudes related to professional 
knowledge, professional practice and professional attributes" (DEST 2002, p. 13).

\section{BASIS OF STANDARDS FRAMEWORK}

The project undertook extensive research of existing teacher professional standards - both ICT and non-ICT specific. The research team concluded that no existing set of standards (either ICT or non-ICT specific) adequately reflected all of the capabilities required of a highly skilled teacher in an ICT rich learning environment. However the project concluded that by modifying the following generic teacher characteristics to include the transformative dimensions of ICT use in teaching and learning, they could form the basis for the development of appropriate ICT specific teacher standards. These generic teacher characteristics are:

- a commitment to students and their learning;

- a deep knowledge and understanding of their subject discipline and of effective pedagogy;

- the ability to implement effective monitoring, assessment and reporting of student progress;

- a commitment to reflect critically on their own practice and to engage in ongoing professional development; and

- a willingness to participate and contribute to the whole educational community at a range of levels.

\section{SETS OF STANDARDS}

A major recommendation of the project was that five sets of ICT specific standards be developed. These standards are not to be specific to levels of education or particular subject areas. The five sets of standards relate to the following recommended target groups:

- pre-service/beginning teachers,

- practicing teachers who are beginning users of ICT,

- practicing teachers who are accomplished/highly accomplished users of ICT,

- school and educational leaders,

- teacher educators. 


\section{SUPPORTING CAPABILITIES}

There is substantial evidence in the literature indicating that a multidimensional approach is needed to successfully implement the use of ICT in schools. In particular, certain conditions must be present in terms of support and institutional capabilities for both teacher education institutions and schools/school systems. These conditions can be referred to as Supporting Capabilities. These capabilities focus on physical, human and financial resources and policy decisions. The project recommended that as part of any national framework, systemic and institutional ICT capabilities be developed for use as part of reviewing, planning and reporting processes.

\section{KEY STAKEHOLDERS}

Findings from the project recognised the critical role of all stakeholders in the process of the development of teacher professional standards. The key stakeholders are the profession, employees, professional associations and education systems. It concluded that there is a need for significant and authentic collaboration between the relevant stakeholders if the development and implementation of teacher professional standards is to be effective and be accepted by the profession.

\section{CONNECTIONS WITH STUDENT STANDARDS AND CURRICULUM}

The project report argues that concurrent with the development of teacher ICT standards, there need to be explicit student ICT specific learning outcomes embedded in curriculum documents, and that any teacher ICT standards should be consistent with student ICT learning outcomes.

\section{THE FUTURE}

The Raising the Standards report was published in July 2002. The recommendations from the report are still under consideration by DEST. The Commonwealth is, however, also undertaking other work in relation to teacher standards and student ICT standards. The MCEETYA Teacher Quality and Educational Leadership taskforce is developing a discussion paper in relation to teacher professional standards. This paper is expected to be released towards the end of 2002. In addition the MCEETYA 
Performance Measurement and Reporting taskforce has begun addressing the issue of student ICT standards. It is anticipated that the Raising the Standards report will inform this work, and in turn any possible future action in relation to teacher ICT-specific standards will be considered in the context of the MCEETYA deliberations.

\section{REFERENCES}

Commonwealth of Australia (1999). Learning in an Online World: The School Education Action Plan for the Information Economy. Retrieved September 9, 2001 from http:// www.detya.gov.au/schools/Publications.

Department of Education, Science and Training (DEST) (2002). Raising the Standards: A Proposal for the Development of an ICT Competency Framework for Teachers. Accessed October $8^{\mathrm{th}}, \quad 2002$ from http://www.dest.gov.au/schools/publications/2002/ raisingstandards.htm

Department of Education, Training and Youth Affairs (DETYA) (2001). Making Better Connections-The Models of Teacher Professional Development for the Integration of ICT into Classroom Practice. Canberra.

Education Department of Western Australia (EDWA) (2001). Competency Framework for Teachers. Murdoch University: Centre for Curriculum and Professional Development.

Education Queensland (1998). Minimum Standards for Teacher-Learning Technology. Retrieved August $8^{\text {th }}, 2002$ from http://education.qld.gov.au/2001/mst_int.htm

Education Queensland (2001). Information and Communications Technology Continua [draft]. Retrieved November $1^{\text {st }}$, 2001 from http:// www.education.qld.gov.au/tal/2001/cont.htm 